\title{
Effects of Copper (Cu) on Yield Components and Associated Traits in Segregating Populations of Lowland Rice (O. sativa L.)
}

\author{
Efisue Andrew ${ }^{1}$, *, Ogunwole Dorcas ${ }^{1}$, Olaoye Olawale ${ }^{2}$ \\ ${ }^{1}$ Department of Crop and Soil Science, Faculty of Agriculture, University of Port Harcourt, Port Harcourt, Nigeria \\ ${ }^{2}$ Department of Soil Science, Faculty of Agriculture, Ahmadu Bello University, Zaria, Nigeria
}

Email address:

andyefisue@yahoo.com (E. Andrew)

${ }^{*}$ Corresponding author

\section{To cite this article:}

Efisue Andrew, Ogunwole Dorcas, Olaoye Olawale. Effects of Copper $(\mathrm{Cu})$ on Yield Components and Associated Traits in Segregating Populations of Lowland Rice (O. sativa L.). International Journal of Genetics and Genomics. Vol. 8, No. 2, 2020, pp. 85-93. doi: $10.11648 /$ j.ijgg.20200802.15

Received: April 17, 2020; Accepted: May 9, 2020; Published: May 18, 2020

\begin{abstract}
Trace elements are very critical for rice growth of which $\mathrm{Cu}$ is one of the essential trace elements for rice and excess of cupper becomes toxic to rice growth. The aim of this study was to determine the productivity increase in rice crop and genotype reactions to application of Copper under the tropical rainforest condition. Three experiments were established concurrently in randomized complete block design in three replications in pots. Treatment comprised of 6 breeding lines each from two rice populations of F2 and F3 generations and two popular checks. Experiment one is the control without $\mathrm{CuSO}_{4}$ treatment, while experiment two and three is the F2 and F3 populations, respectively treated with $\mathrm{CuSO}_{4}$ solution. Three concentration levels of $\mathrm{CuSO}_{4}$ solution $(15 \mathrm{mg} \mathrm{Cu} / \mathrm{kg}$ of soil, $30 \mathrm{mg} \mathrm{Cu} / \mathrm{kg}$ of soil and $60 \mathrm{mg} \mathrm{Cu} / \mathrm{kg}$ of soil) were applied into each pots a week before transplanting in the treated experiments. This study observed that at $30 \mathrm{mg}$ of $\mathrm{Cu} / \mathrm{kg}$ of soil is the optimum level for rice performance based on these experiments beyond, reduction in rice performance. Reduction of $24.92 \%$ and $22.12 \%$ of total grain yield of $\mathrm{F} 2$ and $\mathrm{F} 3$ populations at $60 \mathrm{mg}$ of $\mathrm{Cu} / \mathrm{kg}$ of soil as compared to the control were recorded, stable and high yielding genotypes across the copper concentration levels were identified for copper breeding programme.
\end{abstract}

Keywords: Genotypes, Populations, Micronutrients, GGE Biplot, Rice

\section{Introduction}

Rice is one of the cereal crops globally consumed and is now become a staple crop mostly in Asian countries and part of the developing counties in the world. The demand for rice is far outstrip its production globally and there is need to address some of the limiting factors of rice production at least closing the gap between demand and production of rice. The soil fertility level is depleting annually due to human activities as well, the scenario of global warming thus affecting rice production. Soil micronutrients as the name implied but very important elements in rice production, often, they are one of the most depleted by the aforementioned factors, thus, there is need to mitigate the effects on rice production.
Copper being a transition metal is considered as a trace element with a low concentration in biological tissues but essential for life [1]. Copper was first identified as a plant nutrient and its solubility in soil is greatly dependent on soil $\mathrm{pH}$ and dissolved organic matter content [2] and becomes readily available at a $\mathrm{pH}$ below $6[3,4]$. The requirement of $\mathrm{Cu}$ for healthy plant growth and development varies with plant species and cultivars [5]. Excess $\mathrm{Cu}$ in plants can also be genotoxic, means is capable of generating genetic mutations. In rice roots, excess $\mathrm{Cu}$ specifically altered levels of genes involved in fatty acid metabolism and cellular component biogenesis. Toxic effects of $\mathrm{Cu}$ in plants can be observed by reduction of yield, poor seed germination, stunted leaf and root growth [6, 7]. In plants, $\mathrm{Cu}$ deficiency altered root and leaf construction, as well as significant 
reduction in chlorophyll pigments and photosynthesis [8].

The requirement of $\mathrm{Cu}$ for plant growth particularly rice varies with species and genotypes [5]. Phytotoxicity of $\mathrm{Cu}$ depends mostly on its solubility and availability in the soil. However, the deficiency and excess of $\mathrm{Cu}$ affect plant growth and this could alter important biochemical processes. There are reports on the threshold for $\mathrm{Cu}$ deficiency in plants, however, it depends on crop species and other environmental factors [5]

The plant height of rice was reduced as a result of Copper toxicity [10]. Plant height could be used for assessing crop performance [9]. A report showed that tillering ability is delayed with increasing levels of soil Copper and excess $\mathrm{Cu}$ concentration led to slow recovery from transplanting, delayed tillering and reduction of maximum tiller numbers [10]. Soil $\mathrm{Cu}$ treatments had a large impact on number of spikelets per panicle, which decreased with the increase levels of soil $\mathrm{Cu}$ [10]. The toxic effect of Copper on rice yield significantly increased with increasing level of $\mathrm{Cu}$ concentration. Micronutrient fertilization also referred to agronomic fortification improves crop yield for human consumption, and could also address crop nutritional quality and micronutrient dietary of humans' health [11]. The aim of this study was to determine the productivity increase in rice crop and genotype reactions to the application of Copper under the tropical rainforest condition.

\section{Materials and Methods}

The study was conducted in the screenhouse using soil collected from the experimental farm of the International Institute of Tropical Agriculture (IITA) Onne, (longitude $7^{\circ} 95^{\prime} 28^{\prime \prime} \mathrm{E}$ and latitude $4^{\circ} 43^{\prime} 78^{\prime \prime} \mathrm{N}$ ) in the Humid forest ecological zone of Nigeria. Mean annual rainfall in the zone is $2310.9 \mathrm{~mm}$ and it falls mainly within the months of February to November with peak rainfall received in September. This is a pot experiment and Soil was collected from the research station field at $0-15 \mathrm{~cm}$ depth, sterilized and filled into $4 \mathrm{~kg}$ pot to minimize uneven distribution of $\mathrm{CuSO}_{4}$ in the pots [12]

Three experiments were established concurrently in randomized complete block design in three replications in pots. Treatment comprised of 6 breeding lines each from two rice populations of $\mathrm{F} 2$ and $\mathrm{F} 3$ generations and two popular checks (Table 1.). Experiment one is the control without $\mathrm{CuSO}_{4}$ treatment, while experiment two and three are F2 and F3 populations, respectively treated with $\mathrm{CuSO}_{4}$ solution. Three concentration levels of $\mathrm{CuSO}_{4}$ solution $(15 \mathrm{mg} \mathrm{Cu} / \mathrm{kg}$ of soil, $30 \mathrm{mg} \mathrm{Cu} / \mathrm{kg}$ of soil and $60 \mathrm{mg} \mathrm{Cu} / \mathrm{kg}$ of soil) were applied into each pots a week before transplanting in the treated experiments. The rice seeds were raised in the normal seedling nursery beds with untreated soil. The seedlings were transplanted at 21 days after sowing into treated pots with $\mathrm{CuSO}_{4}[13]$ two seedlings per pot.

Table 1. Genetic material used for the experiment.

\begin{tabular}{llll}
\hline S/N & Genetic materials & Pedigree & Source \\
\hline 1 & UPN 59 & $323845 /$ FARO 44 & Uniport Germplasm Uniport \\
2 & UPN 82 & $323861 /$ UPIA 3 & Uniport Germplasm Uniport \\
3 & UPN 86 & $323865 /$ UPIA 2 & Uniport Germplasm Uniport \\
4 & UPN 95 & $323876 /$ FARO 52 & Uniport Germplasm Uniport \\
5 & UPN 103 & $323879 /$ FARO 44 & Uniport Germplasm Uniport \\
6 & UPN 107 & $323892 /$ FARO 57 & Uniport Germplasm Uniport \\
& Checks & & Uniport Germplasm Uniport \\
7 & FARO 44 & & Uniport Germplasm Uniport \\
8 & UPIA 2 & & Uniport Germplasm Uniport \\
\hline
\end{tabular}

\subsection{Data Collection}

Data was collected at appropriate stage of the crop development. The agronomic characters were measured at weekly intervals. The 'Standard Evaluation System (SES) for Rice' reference manual [14] was used for all trait measurements except where stated otherwise.

\subsection{Statistical Analysis}

Analysis of variance (ANOVA) was performed separately on the individual experiments using the PROC GLM of SAS [15]. Simple linear correlation analysis was performed using the PROC CORR program of SAS. Biplot analysis was employed to investigate the cultivar-by-environment interaction (site regression model) [16]. Biplot construction was based on the first two principal components (PC1 and $\mathrm{PC} 2)$. The $\mathrm{PC} 1$ and $\mathrm{PC} 2$ are referred to as primary and secondary effects, respectively, and were derived from singular-value decomposition (SVD) of the environmentcentred data [16]. The environment-centred data were subjected to SVD for the construction of the biplots. This resulted in three component matrices: singular value (SV) matrix, the cultivar eigenvector matrix, and the environment eigenvector matrix. Thus, the biplot was constructed based on the following model,[17]:

$$
\mathrm{Yij}-\mathrm{G}-\mathrm{Ej}=\sum \lambda \mathrm{n} \sin \eta \mathrm{in}+\varepsilon \mathrm{ij},
$$

where $\mathrm{Yij}=$ the measured mean trait of cultivar $\mathrm{i}$ in environment $j ; G=$ the grand mean; $\mathrm{Ej}=$ the mean effect of environment $j ;(G+E j)$ being the mean trait in environment $j$; $\lambda \mathrm{n}=$ the SVD of nth principal component (PC), the square of which is the sum of square explained by PCn; $\operatorname{cin}=$ the eigenvector of cultivar $\mathrm{i}$ for $\mathrm{PCn}$; $\eta \mathrm{jn}=$ the eigenvector of environment $\mathrm{j}$ for $\mathrm{PCn}$; and $\mathrm{\varepsilon ij}=$ the residual variation associated with genotype $i$ in environment $j$. 


\section{Results}

\subsection{Agronomic Performance of the Tested Genotypes}

Plant height showed highly significant difference among the tested genotypes (Table 2). Plant height increased with increasing concentration of copper in the soil up to $30 \mathrm{mg} \mathrm{Cu}$ $/ \mathrm{kg}$ of soil concentration and declined when above this level. It was observed that genotypes from F2 populations were taller than those from F3 population. These genotypes (UPN 103 and UPN 107), performed better than the overall mean $(98 \mathrm{~cm})$ at $30 \mathrm{mg} \mathrm{Cu} / \mathrm{kg}$ of soil and as well, at F2 and F3 generations. These genotypes performed better than the two checks in all concentration levels of $\mathrm{CuSO}_{4}$ solution (Table 2).

There was a significant difference among all the tested genotypes for maximum number of tillers (Table 3 ). More genotypes including the two checks performed better than the overall mean in all concentration levels. The number of tillers increases with increasing copper concentration up till $30 \mathrm{mg}$ $\mathrm{Cu} / \mathrm{kg}$ of soil and beyond, which the maximum tillering declined. Generally, the F3 population produced more tillers than the F2 population in all concentration levels. Genotype UPN 59 tiller more at $60 \mathrm{mg} \mathrm{Cu} / \mathrm{kg}$ of soil while UPN 86 and UPN 95 had more tillers at $30 \mathrm{mg} \mathrm{Cu} / \mathrm{kg}$ of soil level. (Table 3)

Table 2. Effects of copper concentrations on plant height (cm) of genotypes within F2 and F3 populations.

\begin{tabular}{|c|c|c|c|c|c|c|c|c|}
\hline \multirow{2}{*}{ Genotype } & \multicolumn{2}{|l|}{ Control } & \multicolumn{2}{|c|}{$15 \mathrm{mg}$ of $\mathrm{Cu}$} & \multicolumn{2}{|c|}{ 30mg of CSikirouau } & \multicolumn{2}{|c|}{$60 \mathrm{mg}$ of $\mathrm{Cu}$} \\
\hline & F2 & F3 & F2 & F3 & F2 & F3 & F2 & F3 \\
\hline UPN 59 & $72.50 \mathrm{c}$ & $69.75 \mathrm{de}$ & $77.75 \mathrm{c}$ & $75.50 \mathrm{c}$ & $88.50 \mathrm{c}$ & $81.25 \mathrm{e}$ & $68.25 \mathrm{de}$ & $63.75 \mathrm{~d}$ \\
\hline UPN 86 & $73.75 \mathrm{c}$ & $71.25 \mathrm{~d}$ & $81.75 \mathrm{c}$ & $79.75 c$ & $87.50 \mathrm{c}$ & $85.25 \mathrm{~d}$ & $74.00 \mathrm{c}$ & $71.25 \mathrm{c}$ \\
\hline UPN 95 & $72.25 \mathrm{c}$ & $68.25 \mathrm{ef}$ & $79.00 \mathrm{c}$ & $75.25 \mathrm{c}$ & $87.75 \mathrm{c}$ & $82.00 \mathrm{de}$ & $66.50 \mathrm{ef}$ & $63.25 \mathrm{~d}$ \\
\hline UPN 103 & $87.25 b$ & $77.25 \mathrm{c}$ & $106.50 \mathrm{a}$ & $95.75 \mathrm{a}$ & $123.25 \mathrm{a}$ & $111.00 \mathrm{a}$ & $80.25 b$ & $76.75 b$ \\
\hline UPN 107 & $96.25 \mathrm{a}$ & $94.00 \mathrm{a}$ & $101.00 \mathrm{ab}$ & $90.75 b$ & $119.75 \mathrm{a}$ & $107.50 \mathrm{a}$ & $91.00 \mathrm{a}$ & $87.50 \mathrm{a}$ \\
\hline UPIA 2 & $82.50 \mathrm{~b}$ & $85.25 b$ & $89.75 b c$ & $89.75 b$ & $98.25 b$ & $97.25 b$ & $74.50 \mathrm{c}$ & $73.25 \mathrm{c}$ \\
\hline FARO 44 & $74.75 \mathrm{c}$ & $76.50 \mathrm{c}$ & $78.75 \mathrm{c}$ & $80.00 \mathrm{c}$ & $83.75 c$ & $84.50 \mathrm{de}$ & $70.25 d$ & $71.75 \mathrm{c}$ \\
\hline Mean & 78.69 & 76.03 & 87.16 & 83.34 & 98 & 92.41 & 73.81 & 71.22 \\
\hline Coefficient of variation & 3.58 & 1.49 & 5.72 & 2.27 & 1.94 & 1.67 & 1.33 & 1.33 \\
\hline Level of Significance & $* *$ & $* *$ & $* *$ & $* *$ & $* *$ & $* *$ & $* *$ & $* *$ \\
\hline
\end{tabular}

$* *=$ significant at the $1 \%$.

Table 3. Effect of copper concentration on Maximum number of tillers of genotypes within F2 and F3 population.

\begin{tabular}{|c|c|c|c|c|c|c|c|c|}
\hline \multirow{2}{*}{ Genotype } & \multicolumn{2}{|l|}{ Control } & \multicolumn{2}{|c|}{$15 \mathrm{mg}$ of $\mathrm{Cu}$} & \multicolumn{2}{|c|}{$30 \mathrm{mg}$ of $\mathrm{Cu}$} & \multicolumn{2}{|c|}{$60 \mathrm{mg}$ of $\mathrm{Cu}$} \\
\hline & F2 & F3 & F2 & F3 & F2 & F3 & F2 & F3 \\
\hline UPN 59 & $9.00 \mathrm{abc}$ & $9.75 \mathrm{cde}$ & $11.25 \mathrm{ab}$ & $12.50 \mathrm{bc}$ & 14.00abcd & $15.00 \mathrm{~cd}$ & $10.00 \mathrm{a}$ & $9.25 \mathrm{a}$ \\
\hline UPN 82 & $8.25 b c$ & $9.25 \mathrm{e}$ & $10.00 \mathrm{~b}$ & $11.00 \mathrm{de}$ & $12.75 \mathrm{~cd}$ & $15.50 \mathrm{de}$ & $8.50 \mathrm{~b}$ & $8.75 \mathrm{ab}$ \\
\hline UPN 86 & $9.5 \mathrm{ab}$ & $10.00 \mathrm{bcd}$ & $12.00 \mathrm{a}$ & $13.00 \mathrm{ab}$ & $16.25 \mathrm{a}$ & $17.50 \mathrm{a}$ & $7.75 b$ & $8.75 \mathrm{ab}$ \\
\hline UPN 95 & $9.50 \mathrm{ab}$ & $10.25 \mathrm{abc}$ & $12.25 \mathrm{a}$ & $14.00 \mathrm{a}$ & $14.75 \mathrm{abc}$ & $17.00 \mathrm{ab}$ & $8.25 b$ & $9.00 \mathrm{a}$ \\
\hline UPN 103 & $8.00 \mathrm{c}$ & $9.50 \mathrm{cde}$ & $10.25 b$ & $11.75 \mathrm{~cd}$ & $13.75 \mathrm{bcd}$ & 14.00def & $6.25 \mathrm{c}$ & $8.00 \mathrm{~b}$ \\
\hline UPN 107 & $6.25 \mathrm{~d}$ & $7.75 \mathrm{f}$ & $8.25 \mathrm{c}$ & $10.00 \mathrm{e}$ & $12.00 \mathrm{~d}$ & $13.00 \mathrm{f}$ & $5.00 \mathrm{~d}$ & $5.75 \mathrm{c}$ \\
\hline UPIA 2 & $10.25 \mathrm{a}$ & $10.50 \mathrm{ab}$ & $12.75 \mathrm{a}$ & $13.00 \mathrm{ab}$ & $15.25 \mathrm{ab}$ & $16.00 \mathrm{bc}$ & $8.00 \mathrm{~b}$ & $8.75 \mathrm{ab}$ \\
\hline FARO 44 & $10.25 \mathrm{a}$ & $10.75 a$ & $11.50 \mathrm{ab}$ & $11.50 \mathrm{~cd}$ & $13.25 \mathrm{bcd}$ & $13.50 \mathrm{ef}$ & $8.50 \mathrm{~b}$ & $8.75 \mathrm{ab}$ \\
\hline Mean & 8.88 & 9.72 & 11.03 & 12.09 & 14 & 15.06 & 7.78 & 8.38 \\
\hline $\mathrm{CV}$ & 6.39 & 3.04 & 5.67 & 3.96 & 6.47 & 3.32 & 5.66 & 4.51 \\
\hline LOS & $* *$ & $* *$ & $* *$ & $* *$ & $*$ & $* *$ & $* *$ & $* *$ \\
\hline
\end{tabular}

$*=$ significant at the $5 \%, * *=$ significant at the $1 \%$.

\subsection{Performance of Post-harvest Traits of the Tested Genotypes}

Effective tiller is the tiller that produce economic panicle at the time of harvest, which is very important in the determination of total grain yield of genotype. There was significant difference among all the genotypes both in F2 and $\mathrm{F} 3$ populations in all the $\mathrm{Cu}$ concentration levels except F3 population at $60 \mathrm{mg} \mathrm{Cu} / \mathrm{kg}$ of soil (Table 4 ). The $30 \mathrm{mg} \mathrm{Cu} / \mathrm{kg}$ of soil of copper concentration had the highest effective tillers for all the genotypes and UPN 95 and UPN 86 were highest in $\mathrm{F} 3$ population. At $60 \mathrm{mg} \mathrm{Cu} / \mathrm{kg}$ of soil, all genotype had reduction in effective tiller number, while FARO 44 had the highest number of effective tillers (Table 4). 
Table 4. Effect of Copper concentration on effective tillers of genotypes within $F 2$ and F3 population.

\begin{tabular}{lllllllll}
\hline \multirow{2}{*}{ Genotypes } & Control & & $\mathbf{1 5 m g}$ of $\mathbf{C u}$ & & $\mathbf{3 0 m g}$ of $\mathbf{C u}$ & & $\mathbf{6 0 m g}$ of $\mathbf{C u}$ \\
\cline { 2 - 9 } & $\mathbf{F 2}$ & $\mathbf{F 3}$ & $\mathbf{F 2}$ & $\mathbf{F 3}$ & $\mathbf{F 2}$ & $\mathbf{F 3}$ & $\mathbf{F 2}$ & $\mathbf{F 3}$ \\
\hline UPN 59 & $6.25 \mathrm{ab}$ & $7.50 \mathrm{ab}$ & $8.00 \mathrm{~cd}$ & $10.25 \mathrm{ab}$ & $11.75 \mathrm{ab}$ & $12.50 \mathrm{abc}$ & $4.00 \mathrm{c}$ & $6.00 \mathrm{ab}$ \\
UPN 82 & $6.50 \mathrm{ab}$ & $7.50 \mathrm{ab}$ & $8.50 \mathrm{c}$ & $8.75 \mathrm{~cd}$ & $10.75 \mathrm{bc}$ & $12.00 \mathrm{bc}$ & $4.75 \mathrm{bc}$ & $5.75 \mathrm{ab}$ \\
UPN 86 & $6.25 \mathrm{ab}$ & $7.75 \mathrm{ab}$ & $9.25 \mathrm{~b}$ & $10.00 \mathrm{ab}$ & $13.00 \mathrm{a}$ & $13.75 \mathrm{a}$ & $5.00 \mathrm{bc}$ & $6.00 \mathrm{ab}$ \\
UPN 95 & $7.50 \mathrm{a}$ & $7.50 \mathrm{ab}$ & $9.25 \mathrm{~b}$ & $10.75 \mathrm{a}$ & $12.50 \mathrm{ab}$ & $13.75 \mathrm{a}$ & $4.00 \mathrm{c}$ & $5.50 \mathrm{abc}$ \\
UPN 103 & $5.50 \mathrm{bc}$ & $6.75 \mathrm{~b}$ & $7.75 \mathrm{~d}$ & $8.50 \mathrm{~cd}$ & $11.75 \mathrm{ab}$ & $11.75 \mathrm{c}$ & $4.00 \mathrm{c}$ & $5.25 \mathrm{bc}$ \\
UPN 107 & $4.00 \mathrm{c}$ & $4.75 \mathrm{c}$ & $7.00 \mathrm{e}$ & $7.75 \mathrm{~d}$ & $9.00 \mathrm{c}$ & $10.00 \mathrm{~d}$ & $3.75 \mathrm{c}$ & $4.00 \mathrm{c}$ \\
UPIA 2 & $7.75 \mathrm{a}$ & $7.75 \mathrm{ab}$ & $10.75 \mathrm{a}$ & $11.00 \mathrm{a}$ & $12.75 \mathrm{ab}$ & $13.25 \mathrm{ab}$ & $5.50 \mathrm{ab}$ & $5.50 \mathrm{abc}$ \\
FARO 44 & $8.00 \mathrm{a}$ & $8.25 \mathrm{a}$ & $9.50 \mathrm{~b}$ & $9.50 \mathrm{bc}$ & $12.00 \mathrm{ab}$ & $12.25 \mathrm{bc}$ & $6.75 \mathrm{a}$ & $7.00 \mathrm{a}$ \\
Mean & 6.47 & 7.22 & 8.75 & 9.56 & 11.69 & 12.41 & 4.72 & 5.63 \\
Coefficient of variation & 11.29 & 6.89 & 2.86 & 4.74 & 7.05 & 4.29 & 11.97 & 12.11 \\
Level of Significance & $*$ & $* *$ & $* *$ & $* *$ & $*$ & $* *$ & $*$ & Ns \\
\hline
\end{tabular}

$\mathrm{Ns}=$ not significant, $*=$ significant at the $5 \%, * *=$ significant at the $1 \%$.

1000 grain weight for the populations as influenced by copper concentrations. For all the genotype tested, significant difference was observed in $\mathrm{F} 3$ populations for the three levels of $\mathrm{CuSO}_{4}$ solution and the control experiment (Table 5). Similar trend was observed as in Table 4 in-terms of increase in $\mathrm{Cu}$ concentration and the corresponding increase in traits value for the tested genotypes. The grand mean of F3 at $60 \mathrm{mg}$ of $\mathrm{Cu}$ was the lowest (Table 5).

Table 5. Effect of Copper concentration on 1000 grain weight of genotypes within F2 and F3 population.

\begin{tabular}{|c|c|c|c|c|c|c|c|c|}
\hline \multirow{2}{*}{ Genotype } & \multicolumn{2}{|l|}{ Control } & \multicolumn{2}{|c|}{$15 \mathrm{mg}$ of $\mathrm{Cu}$} & \multicolumn{2}{|c|}{$30 \mathrm{mg}$ of $\mathrm{Cu}$} & \multicolumn{2}{|c|}{$60 \mathrm{mg}$ of $\mathrm{Cu}$} \\
\hline & F2 & F3 & F2 & F3 & F2 & F3 & F2 & F3 \\
\hline UPN 59 & 22.50 & $22.00 \mathrm{ab}$ & $23 a b$ & $22.25 \mathrm{ab}$ & 22.75 & $21.75 \mathrm{de}$ & 22.50 & $21.25 \mathrm{c}$ \\
\hline UPN 82 & 22.25 & $21.50 \mathrm{~b}$ & $22.75 \mathrm{ab}$ & $22.00 \mathrm{~b}$ & 22.50 & $21.50 \mathrm{e}$ & 22.5 & $20.75 c$ \\
\hline UPN 86 & 22.25 & $21.50 \mathrm{~b}$ & $22.75 \mathrm{ab}$ & $22.00 \mathrm{~b}$ & 23.00 & $22.00 \mathrm{cde}$ & 22.25 & $20.75 c$ \\
\hline UPN 95 & 22.75 & $22.00 \mathrm{ab}$ & $22.50 \mathrm{~b}$ & $22.25 \mathrm{ab}$ & 22.75 & $22.25 \mathrm{bcd}$ & 22.50 & $21.50 \mathrm{abc}$ \\
\hline UPN 103 & 23.00 & $21.50 \mathrm{~b}$ & $23.25 \mathrm{a}$ & $22.25 \mathrm{ab}$ & 23.00 & $22.50 \mathrm{bc}$ & 22.75 & $21.75 \mathrm{ab}$ \\
\hline UPIA 2 & 23.00 & $22.75 \mathrm{a}$ & $22 \mathrm{ab}$ & $23.00 \mathrm{a}$ & 23.00 & $23.25 \mathrm{a}$ & 22.25 & $22.25 \mathrm{a}$ \\
\hline FARO 44 & 22.500 & $22.50 \mathrm{a}$ & $22.75 \mathrm{ab}$ & $22.75 \mathrm{ab}$ & 22.75 & $22.75 \mathrm{ab}$ & 22.25 & $22.25 \mathrm{a}$ \\
\hline Mean & 22.63 & 21.88 & 22.78 & 22.13 & 22.84 & 22.25 & 22.41 & 21.5 \\
\hline Coefficient of variation & 1.87 & 1.49 & 1.15 & 1.71 & 0.99 & 1.12 & 2.06 & 1.46 \\
\hline Level of Significance & ns & $*$ & $\mathrm{~ns}$ & $* *$ & ns & $* *$ & $\mathrm{~ns}$ & $*$ \\
\hline
\end{tabular}

$\mathrm{ns}=$ not significant, $*=$ significant at the $5 \%, * *=$ significant at the $1 \%$.

For panicle length, there was significant difference among all the genotypes both in F2 and F3 populations in all the $\mathrm{Cu}$ concentration levels except at $\mathrm{F} 3$ population at $30 \mathrm{mg}$ of $\mathrm{Cu}$ and $60 \mathrm{mg} \mathrm{Cu} / \mathrm{kg}$ of soil (Table 6). It was observed that the two checks (UPIA 2 and FARO 44) had longer panicles than the test genotypes and F3 populations had longer panicle length than F2 in all the experiments. (Table 6).

The grain yield (GY) per hectare increased with increasing copper concentration in the soil but decreased at $60 \mathrm{mg} \mathrm{Cu} / \mathrm{kg}$ of soil. There is no significant difference among the genotypes in both $\mathrm{F} 2$ and $\mathrm{F} 3$ populations at $60 \mathrm{mg} \mathrm{Cu} / \mathrm{kg}$ of soil (Table 7). The F3 populations perform better than the F2 population in all $\mathrm{Cu}$ concentration levels based on grain yield. The UPN 59, UPN 82 and UPN 86 were among the best yielded tested genotypes in all $\mathrm{Cu}$ concentration and population levels. (Table 7)

Table 6. Effect of Copper concentration on Panicle length of genotypes within F2 and F3 population.

\begin{tabular}{|c|c|c|c|c|c|c|c|c|}
\hline \multirow{2}{*}{ Genotype } & \multicolumn{2}{|l|}{ Control } & \multicolumn{2}{|c|}{$15 \mathrm{mg}$ of $\mathrm{Cu}$} & \multicolumn{2}{|c|}{$30 \mathrm{mg}$ of $\mathrm{Cu}$} & \multicolumn{2}{|c|}{$60 \mathrm{mg}$ of $\mathrm{Cu}$} \\
\hline & F2 & F3 & F2 & F3 & F2 & F3 & F2 & F3 \\
\hline UPN 59 & $22.25 d$ & $25.00 \mathrm{ab}$ & $24.50 \mathrm{ab}$ & $25.25 \mathrm{c}$ & $25.25 b$ & $26.00 \mathrm{ab}$ & $19.25 \mathrm{e}$ & $24.00 \mathrm{a}$ \\
\hline UPN 82 & $20.75 \mathrm{e}$ & $24.00 \mathrm{c}$ & $22.00 \mathrm{c}$ & $25.00 \mathrm{c}$ & $23.00 \mathrm{c}$ & $25.25 b$ & $19.25 \mathrm{e}$ & $21.75 b$ \\
\hline UPN 86 & $22.50 \mathrm{~cd}$ & $24.50 \mathrm{bc}$ & $23.25 b c$ & $25.25 \mathrm{c}$ & $23.75 c$ & $25.75 \mathrm{ab}$ & $23.25 b c$ & $24.50 \mathrm{a}$ \\
\hline UPN 95 & $21.75 \mathrm{de}$ & $25.00 \mathrm{ab}$ & $22.75 \mathrm{c}$ & $25.00 \mathrm{c}$ & $22.75 c$ & $25.75 \mathrm{ab}$ & $21.75 \mathrm{~d}$ & $24.25 \mathrm{a}$ \\
\hline UPN 103 & $24.25 b$ & $25.50 \mathrm{a}$ & $24.50 \mathrm{ab}$ & $25.25 \mathrm{c}$ & $25.50 \mathrm{ab}$ & $26.50 \mathrm{ab}$ & $22.75 \mathrm{dc}$ & $23.50 \mathrm{ab}$ \\
\hline UPIA 2 & $25.75 a$ & $25.75 a$ & $25.75 a$ & $26.00 \mathrm{ab}$ & $26.50 \mathrm{a}$ & $26.50 \mathrm{ab}$ & $25.25 \mathrm{a}$ & $25.25 \mathrm{a}$ \\
\hline FARO 44 & $23.75 b c$ & $23.75 \mathrm{c}$ & $25.50 \mathrm{a}$ & $25.50 \mathrm{bc}$ & $26.00 \mathrm{ab}$ & $26.00 \mathrm{ab}$ & $24.75 \mathrm{a}$ & $24.50 \mathrm{a}$ \\
\hline Mean & 23.19 & 24.88 & 24.22 & 25.44 & 24.84 & 26.09 & 22.56 & 24.06 \\
\hline
\end{tabular}




\begin{tabular}{lllllllll}
\hline \multirow{2}{*}{ Genotype } & Control & & 15mg of $\mathbf{C u}$ & 30mg of $\mathbf{C u}$ & & $\mathbf{6 0 m g}$ of $\mathbf{C u}$ \\
\cline { 2 - 9 } & $\mathbf{F 2}$ & $\mathbf{F 3}$ & $\mathbf{F 2}$ & $\mathbf{F 3}$ & $\mathbf{F 2}$ & $\mathbf{F 3}$ & $\mathbf{F 2}$ & $\mathbf{F 3}$ \\
\hline Coefficient of variation & 2.41 & 1.26 & 2.13 & 1.05 & 1.77 & 1.98 & 2.33 & 3.33 \\
Level of Significance & $* *$ & $* *$ & $* *$ & $*$ & $* *$ & $\mathrm{~ns}$ & $* *$ & $\mathrm{~ns}$ \\
\hline
\end{tabular}

ns $=$ not significant $*=$ significant at the $5 \%, * *=$ significant at the $1 \%$.

Table 7. Effect of Copper concentration on yield of genotypes (t/ha) within F2 and F3 population.

\begin{tabular}{|c|c|c|c|c|c|c|c|c|}
\hline \multirow{2}{*}{ Genotypes } & \multicolumn{2}{|c|}{ Control } & \multicolumn{2}{|c|}{$15 \mathrm{mg}$ of $\mathrm{Cu}$} & \multicolumn{2}{|c|}{$30 \mathrm{mg}$ of $\mathrm{Cu}$} & \multicolumn{2}{|c|}{$60 \mathrm{mg}$ of $\mathrm{Cu}$} \\
\hline & F2 & F3 & F2 & F3 & F2 & F3 & F2 & F3 \\
\hline UPN 59 & $4.19 a$ & $4.69 a$ & $5.37 \mathrm{ab}$ & $5.96 a$ & 5.86bcd & $6.45 \mathrm{ab}$ & $3.13 \mathrm{ab}$ & $4.19 a$ \\
\hline UPN 82 & $4.00 \mathrm{ab}$ & $4.69 a$ & $5.18 b c$ & $5.27 \mathrm{bc}$ & $5.76 \mathrm{~cd}$ & $5.62 \mathrm{~b}$ & $3.32 \mathrm{a}$ & $3.71 \mathrm{ab}$ \\
\hline UPN 86 & $4.00 \mathrm{ab}$ & $4.49 \mathrm{ab}$ & $5.57 \mathrm{a}$ & $5.86 \mathrm{ab}$ & $6.74 a$ & $6.93 a$ & $3.32 \mathrm{a}$ & $3.71 \mathrm{ab}$ \\
\hline UPN 95 & $4.29 \mathrm{a}$ & $4.49 \mathrm{ab}$ & $5.37 \mathrm{ab}$ & $5.76 \mathrm{ab}$ & $6.35 \mathrm{abc}$ & $6.93 a$ & $2.93 \mathrm{ab}$ & $3.42 \mathrm{abc}$ \\
\hline UPN 103 & $3.14 b c$ & $3.81 b c$ & $4.39 \mathrm{~d}$ & $4.79 c$ & $5.76 \mathrm{~cd}$ & $6.05 \mathrm{ab}$ & $2.73 b$ & $3.32 \mathrm{abc}$ \\
\hline UPIA 2 & $4.19 a$ & $4.29 \mathrm{ab}$ & $5.18 b c$ & $5.27 b c$ & $6.45 \mathrm{ab}$ & $6.74 \mathrm{ab}$ & $3.22 \mathrm{a}$ & $3.22 \mathrm{bc}$ \\
\hline FARO 44 & $4.00 \mathrm{ab}$ & $4.00 \mathrm{abc}$ & $4 . .88 \mathrm{c}$ & $4.88 \mathrm{c}$ & $5.66 \mathrm{~d}$ & $5.76 \mathrm{ab}$ & $3.42 \mathrm{a}$ & $3.52 \mathrm{abc}$ \\
\hline Mean & 3.91 & 4.25 & 5.03 & 5.32 & 5.94 & 6.26 & 3.13 & 3.48 \\
\hline Coefficient of Variation & 6.55 & 6.67 & 2.54 & 4.6 & 4.19 & 7.93 & 6.14 & 9.94 \\
\hline Level of Variation & * & * & $* *$ & $* *$ & $* *$ & ns & ns & ns \\
\hline
\end{tabular}

$\mathrm{ns}=$ not significant, $*=$ significant at the $5 \%, * *=$ significant at the $1 \%$.

\subsection{Phenotypic Correlation Among Traits in the Populations}

Grain yield (GY) showed positive and significant correlation with tiller number, effective tiller, number of panicles per plant, plant height and 1000 grain weight. The 1000 grain weight had positive correlation with all plant growth parameters except with plant height (Table 8). The panicle length significantly $(\mathrm{P} \leq 0.01)$ and positively correlated with plant height, number of tiller and effective tiller number (Table 8).

\subsection{GGEbiplot Analyses}

The first two principal components (PC1 and PC2) obtained by SVD of the centred data explained $94.6 \%$ of the total variation for grain yield in F2 population (Figure 1), while the first two principal components ( $\mathrm{PCl}$ and $\mathrm{PC} 2$ ) accounted for $92 \%$ of the total variation for grain yield in $\mathrm{F} 3$ populations (Figure 2). Three mega environments were identified for the two populations, environment one comprised the control $\mathrm{C} 0$ and $\mathrm{C} 1(15 \mathrm{mg} \mathrm{Cu} / \mathrm{kg}$ of soil), while environment two and three were $\mathrm{Cu} 2(30 \mathrm{mg}$ of $\mathrm{Cu} / \mathrm{kg}$ of soil), and $\mathrm{C} 3(60 \mathrm{mg}$ of $\mathrm{Cu} / \mathrm{kg}$ of soil), respectively (Figure 1 and
Figure 2). The environment two and three were opposite of both side of the perpendicular double-headed arrows indicated the mean grain yield of the experiments. Environment one for both populations is very closed to the appendicular line, which indicates to be close to an ideal environment for the experiment. The genotypes at the vertices of the pentagon had highest GY at that environment, UPN 86 and UPN 95 had the highest GY in environment one and two respectively, while FARO 44 yield highest in environment three for F2 and UPN 59 for F3 population (Figure 1 and Figure 2).

Performances of genotypes were ranked in the direction indicated by the single-headed arrow (average tester coordinate) in ascending order of the mean grain yield of the experiments. Therefore, Stability of genotypes was ranked on the basis of their projection from the average tester coordinate (axis) on the average environment main effect. The greater the length of the projection of a genotype, the more unstable that genotype was (Figure 3 and Figure 4). The most stable genotype for F2 were UPN 59 and UPIA 2, while UPN 82 and UPN 86 for F3 population. The highest yielding genotype were UPN 86 and UPN 59 for F2 and F3 populations, respectively (Figure 3 and Figure 4).

Table 8. Linear correlation coefficient of growth and yield parameters for $F 2$ and $F 3$ population (Copper environment).

\begin{tabular}{|c|c|c|c|c|c|c|c|}
\hline TRAITS & PHT-C2 & NTI_C2 & ET_C2 & PAL_C2 & NPPP_C2 & 1000GWT_C2 & YLD_C2 \\
\hline PHT-C3 & & & & & & & \\
\hline NTI_C3 & $0.39 \mathrm{~ns}$ & & & & & & \\
\hline ET_C3 & $0.40 *$ & $0.95 * * *$ & & & & & \\
\hline PAL_C3 & $0.66 * *$ & $0.50 * *$ & $0.57 * *$ & & & & \\
\hline NPPP_C3 & $0.36^{*}$ & $0.90 * * *$ & $0.90 * * *$ & $0.34 *$ & & & \\
\hline 1000GWT_C3 & $0.20 \mathrm{~ns}$ & $0.51 *$ & $0.56 * *$ & $0.51^{*}$ & $0.56^{* *}$ & & \\
\hline YLD_C3 & $0.31 * *$ & $0.64 * *$ & $0.65^{* *}$ & $0.11 \mathrm{~ns}$ & $0.65 * *$ & $0.58 * *$ & \\
\hline
\end{tabular}

$\mathrm{C} 2$ and $\mathrm{C} 3$ at the end of variables represent $\mathrm{F} 2$ and $\mathrm{F} 3$ populations, respectively. ns $=$ not significant, $*=$ significant at $5 \%, * *=$ significant at $1 \%$, $* * *=$ significant at $01 \%, \mathrm{~ns}=$ not significant, $\mathrm{PHT}=$ Plant height, NTI=Number of tillers, ET=Effective tillers, PAL $=$ Panicle Length, NPPP=Number of Panicle per Plant, 1000-GWT=1000 grain weight, YLD=Yield/ha. 


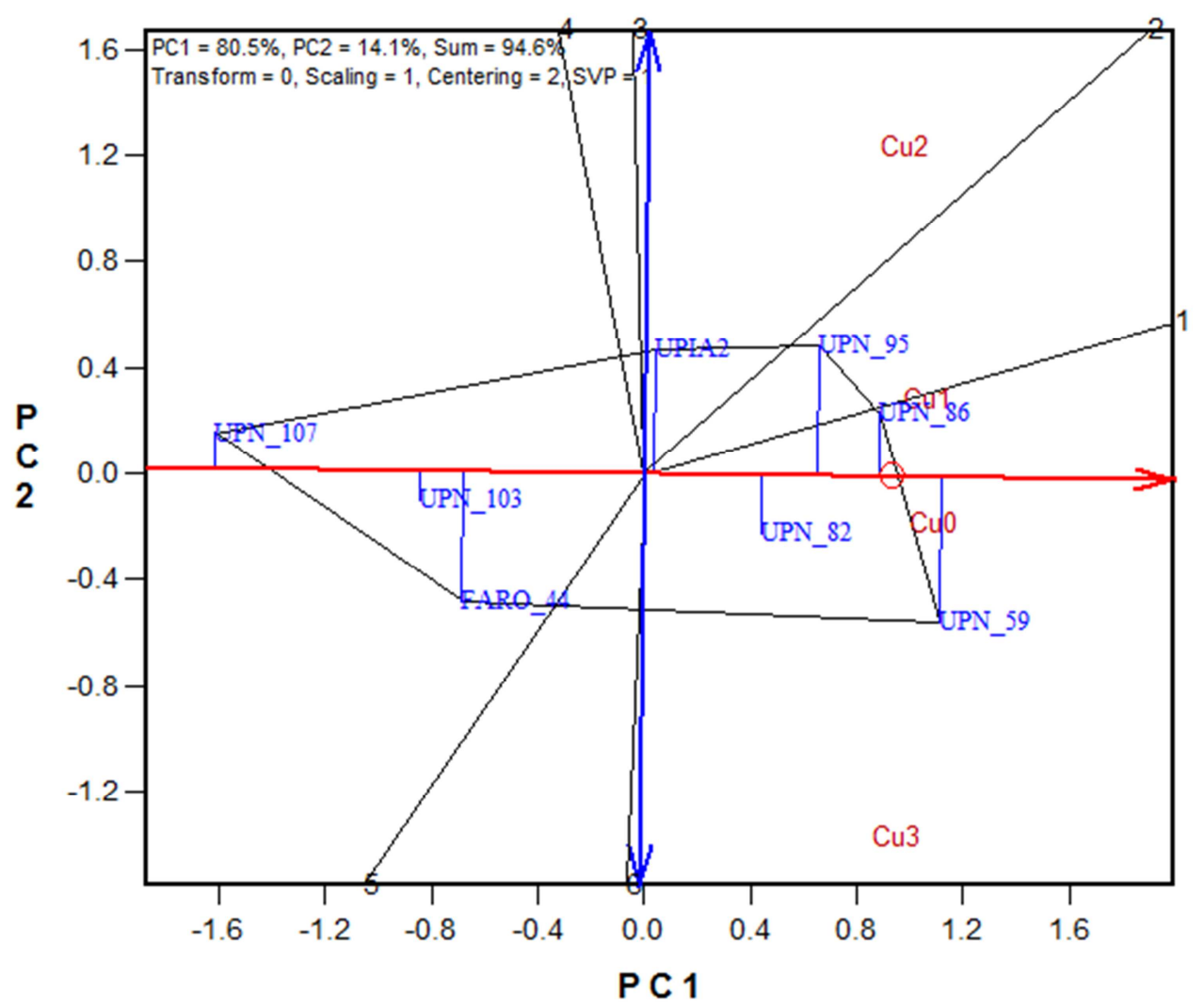

Figure 1. F2 Cu which wins where.

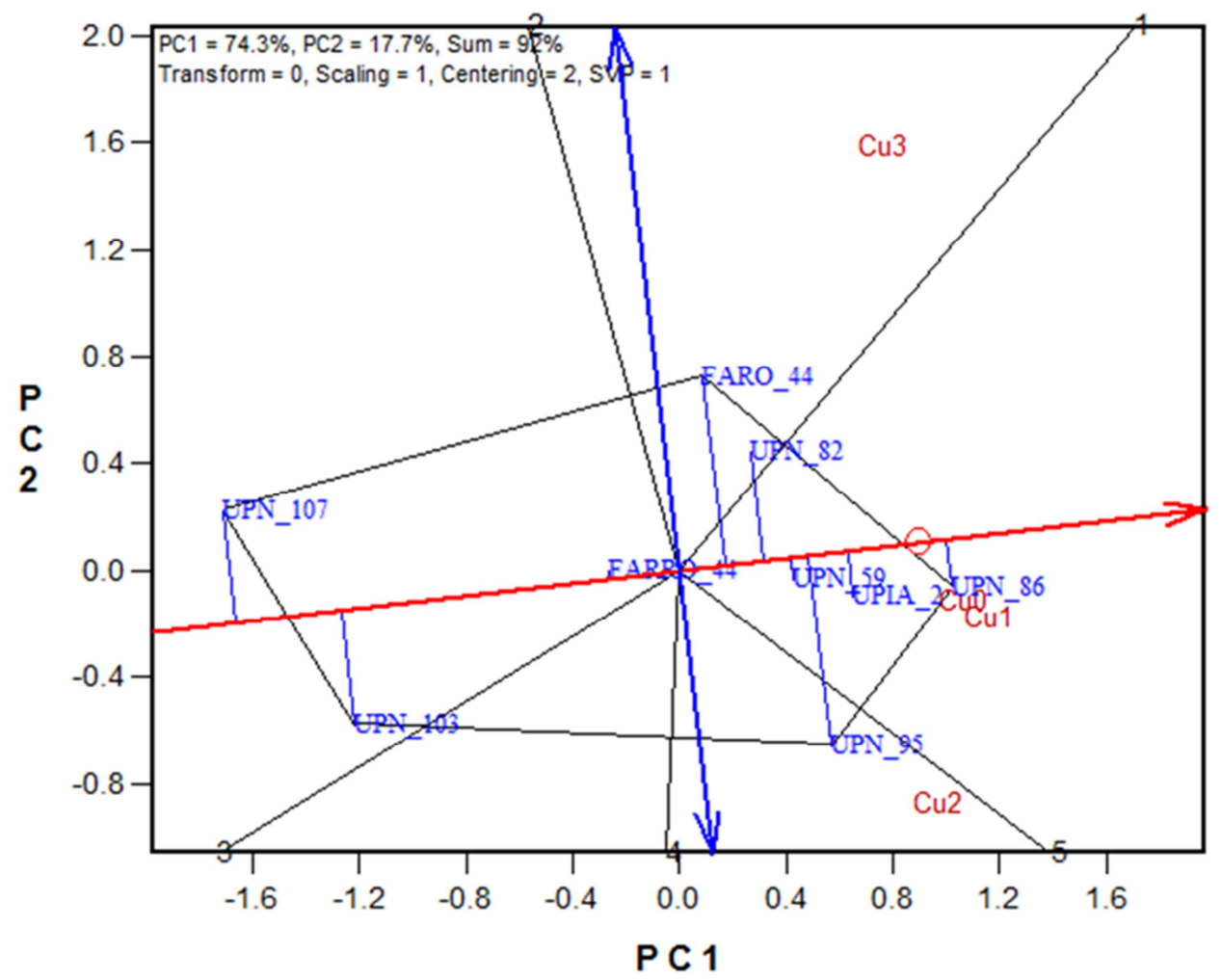

Figure 2. $\mathrm{F3} \mathrm{Cu}$ which wins where. 


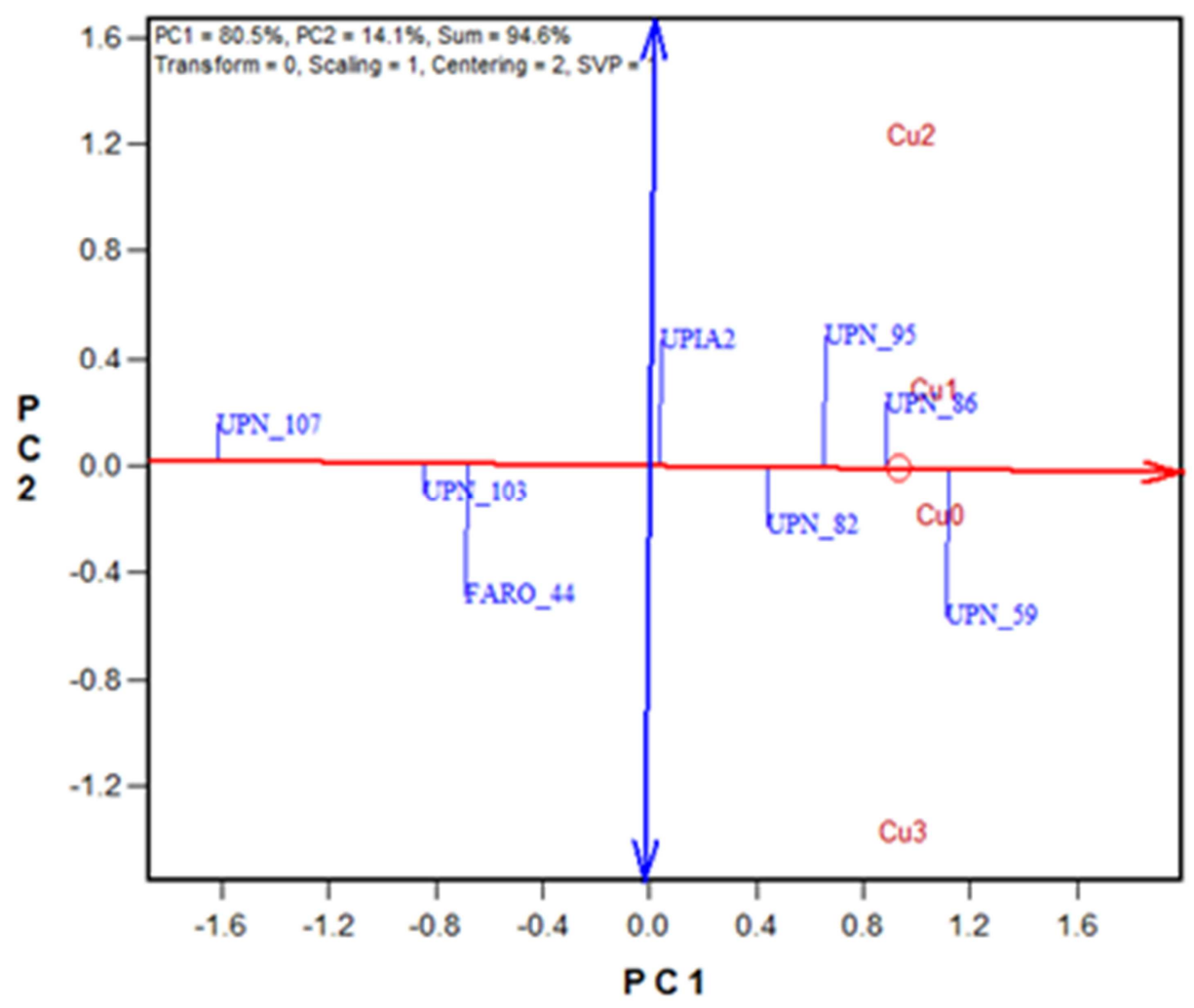

Figure 3. F2 Cu GGE biplot analysis of Yield.

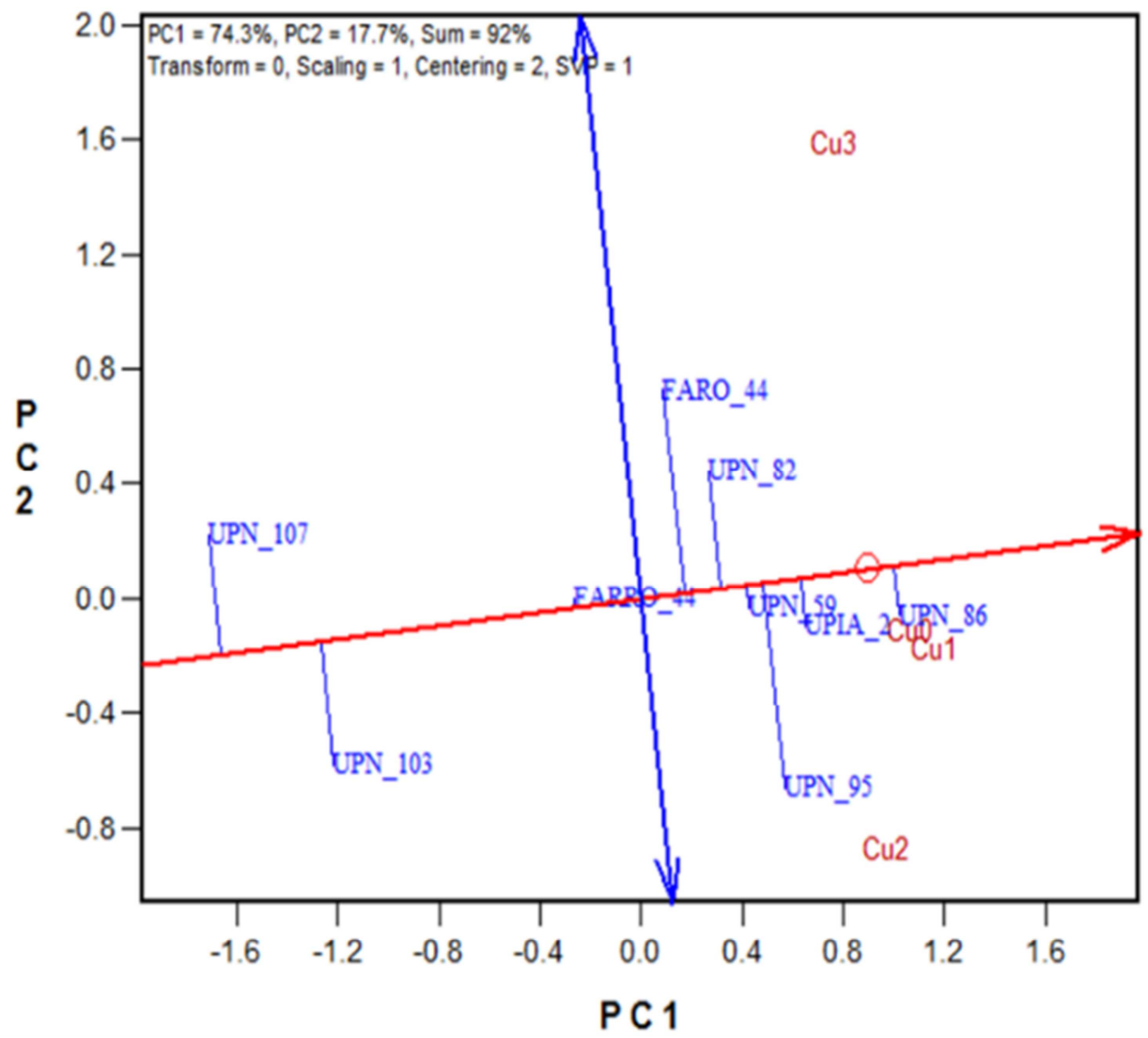

Figure 4. F3 Cu GGE biplot analysis of yield. 


\section{Discussion}

\subsection{Agronomic Performance of the Tested Genotypes}

Micronutrient elements are very important for rice growth of which $\mathrm{Cu}$ is one of the essential trace elements for rice. As a trace element, copper is also an enzyme cofactor and played an important role in the inhibition of plant uptake of toxic trace elements. Plant height is a parameter for assessing crop performance [9]. This present finding revealed that Plant height increased with increasing in concentration $\mathrm{CuSO}_{4}$ solution up to $30 \mathrm{mg}$ of $\mathrm{Cu} / \mathrm{kg}$ of soil level and decreased when soil at $60 \mathrm{mg}$ of $\mathrm{Cu} / \mathrm{kg}$ of soil. In rice, plant height was reduced as a result of Copper toxicity [10], although UPN 103 and UPN 107 were the tallest even at high copper concentration, however, smaller plants do not necessarily affect yield, especially in the absence of water stress [18].

In most abiotic stressed environments, rice crop performed very well to some concentration levels, beyond, which experienced decline in performance. In this study, tiller number increased up to $(30 \mathrm{mg}$ of $\mathrm{Cu} / \mathrm{kg}$ of soil) and decreased at $(60 \mathrm{mg}$ of $\mathrm{Cu} / \mathrm{kg}$ of soil), this corroborate the report on $\mathrm{Cu}$ in wheat [6]. Similar report on salinity and its effects on tillering ability on rice $[19,20]$. The increase in tiller number even at high level $60 \mathrm{mg}$ of $\mathrm{Cu} / \mathrm{kg}$ of soil may be attributed to the nitrogen fixation an attribute of copper as well as the role of Copper in biochemical processes like photosynthesis and respiration [21]. It was observed that F3 populations had more tiller numbers than the F2, this could be due to biased selections made at early stages of the crops.

\subsection{Performance of Post-harvest Traits of the Tested Genotypes}

The effective tillers which, is the number of tillers harvestable per plant, is very important in the determination of total grain yield of genotype. This study showed that the optimal level of copper concentration is at $30 \mathrm{mg} \mathrm{Cu} / \mathrm{kg}$ of soil, where all the genotypes hard the highest numbers of effective tiller both in F2 and F3 populations. Reports also showed that there was $10 \%$ reduction on the rice performance at $100 \mathrm{mgCu} \mathrm{kg}-1$ and beyond, reduction by $50 \%$ in rice performance $[22,23]$. The genotypes UPN 95 and UPN 86 had more effective tiller number even at $60 \mathrm{mg}$ of $\mathrm{Cu} / \mathrm{kg}$ of soil, which could be used for population improvement in copper breeding programme.

The 1000 grain weight and panicle length are major yield components that determine the ultimate grain yield of rice. The panicle length determines the number of grains to be accommodated and higher grain yield for varieties with longer panicle length have been reported [24]. Most of the genotypes tested had high values of 1000 grain weight and long panicle length even at $60 \mathrm{mg}$ of $\mathrm{Cu} / \mathrm{kg}$ of soil, which could be deployed to copper stressed environments.

The genotype UPN 59 performed better based on grain yield across in all copper concentration levels. Therefore, this genotype could a potential variety in copper stressed environment. Reduction of $24.92 \%$ and $22.12 \%$ of total grain yield of $\mathrm{F} 2$ and $\mathrm{F} 3$ populations at $60 \mathrm{mg}$ of $\mathrm{Cu} / \mathrm{kg}$ of soil as compared to the control were recorded, the performance of F3 populations could be biased selection at the early generation of the crop. The decrease in grain yield as compared to the control could be a combination from the effects of yield components in $\mathrm{Cu}$ treated experiments as stated earlier.

\subsection{Phenotypic Correlation Among Traits in the Populations}

The grain yield had significant correlation at probability of 0.01 with plant height, effective tiller, 1000 grain weight. These results corroborate earlier reports $[25,19]$. The existence of correlation may be attributed to the presence of linkage or pleiotropic effect of genes or environmental effect or combination of all [26]. The significant and positive correlation values observed could be used as secondary traits for yield selection especially, in early generation of the varietal development in rice.

\subsection{GGEbiplot Analyses}

The GGE refers to the genotype main effect (G) and the genotype $\mathrm{x}$ environment interaction (GE), which are the two most important sources of variation for cultivar evaluation in a multi environment trials [27]. GGE has been recognized as a useful tool to analyze and visualize the pattern of genotype $x$ environment interaction of cultivar in multi environment and evaluation of different crops including cereals [27, 20]. Three mega environments were identified and could assist the breeders in prioritizing screening environments and genotypes for each environment as UPN 86 and UPN 95 had the highest GY in environment one and two, respectively. Screening for copper resistant genotypes at the early generation of the breeding cycle will assist breeders to reduce the number of genotypes to be carried into the next breeding cycles of the programme. The most stable genotype for F2 were UPN 59 and UPIA 2, while UPN 82 and UPN 86 for F3 population. The highest yielding genotype were UPN 86 and UPN 59 for F2 and F3 populations, respectively, these promising genotypes could accelerate breeding for copper resistance and immediate deployment to copper stressed environments.

\section{Conclusion}

Trace elements are very critical for rice growth of which $\mathrm{Cu}$ is one of the essential trace elements for rice. Selecting and breeding staple food crops which are more efficient in the uptake of micronutrients from the soil are beneficial for agricultural productivity. This study observed that $30 \mathrm{mg}$ of $\mathrm{Cu} / \mathrm{kg}$ of soil is an optimum level for rice performance based on these experiments beyond, which reduction in rice performance. Reduction of $24.92 \%$ and $22.12 \%$ of total grain yield of $\mathrm{F} 2$ and $\mathrm{F} 3$ populations at $60 \mathrm{mg}$ of $\mathrm{Cu} / \mathrm{kg}$ of soil as compared to the control were recorded, stable and high 
yielding genotypes across the copper concentration levels were identified for copper breeding programme.

\section{Acknowledgements}

Authors wish to express their gratitude to KAFAC of RDA Korea for providing the genetic materials (anther culture derived) used for this study.

\section{References}

[1] Alloway, B. J. (1995). Heavy metals in soils (Ed.). Blackie Academic and Professional, London.

[2] Bravin, M. N., Garnier, C., Lenoble, V., Gérard, F., Dudal, Y. and Hinsinger, P. (2012). Root-induced changes in $\mathrm{pH}$ and dissolved organic matter binding capacity affect copper dynamic speciation in the rhizosphere. Geochim Cosmochim Acta 84: 256-268.

[3] Adriano, D. C. (2001). Trace elements in terrestrial environments: biogeochemistry, bioavailability, and risks of metals, 2nd edn. Springer, New York.

[4] Brun, L. A., Maillet, J., Hinsinger, P. and Pépin, M. (2001). Evaluation of copper availability to plants in coppercontaminated vineyard soils. Environ Pollut 111: 293-302.

[5] Mantovi, P., Bonazzi, G., Maestri, E. and Marmiroli, N. (2003). Accumulation of copper and zinc from liquid manure in agricultural soils and crop plants. Plant Soil 250: 249-257.

[6] Kumar, P., Tewari, R. K. and Sharma, P. N. (2008). Modulation of copper toxicity induced oxidative damage by excess supply of iron in maize plants. Plant Cell Replication, 27: 399-409.

[7] Azooz, M. M, Abou-Elhamd, M. F. and Al-Fredan, M. A. (2012). Biphasic effect of copper on growth, proline, lipid peroxidation and antioxidant enzyme activities of wheat (Triticum aestivum'cv. Hasaawi) at early growing stage. Aust J Crop Sci 6: 688-694.

[8] Yruela, I (2009). Copper in plants: acquisition, transport and interactions. Funct Plant Biol 36: 409-430.

[9] Tittonell, P. (2005). Estimating yields of tropical maize genotypes from non-destructive, on-farm plant morphological measurements. Agriculture, Ecosystems and Environment, 105: $213-220$

[10] Xu, J., Yang, L., Wang, Z., Dong, G., Huang, J. And Wang, Y. (2005). Effects of Soil Copper Concentration on Growth, Development and Yield Formation of Rice (Oryza sativa). Rice Science, 12 (2): 125-132.

[11] Christian, O. Dimkpa, P. and Bindraban, S. (2016). Fortification of micronutrients for efficient agronomic production: a review. Agronomy for Sustainable Development, 36 (1): 7.

[12] Saikia, T. and Baruah, K. K. (2012). Iron toxicity tolerance in rice (Oryza sativa) and its association with anti-oxidative enzyme activity. Journal of Crop Science, 3, 90.

[13] Sikiroua Mouritala, Kazuki Saitob, Khady Nani Draméc, Aliou Saidoua, Ibnou Diengb, Adam Ahanchédéa and Ramaiah Venuprasadd (2016) Soil-based screening for iron toxicity tolerance in rice using pots. Plant Production Science, 19 (4): 489-496.

[14] International Rice Research Institute (IRRI). 1996. Standard evaluation system for rice (SES). Los Baanos, Philippines: IRRI

[15] SAS Institute Inc. 2003. SAS/STAT user's guide, version 9.1. Cary, NC: SAS Institute Inc.

[16] Yan, W., P. L. Cornelius, J. Crossa, and L. A. Hunt. 2001. Two types of GGE biplots for analyzing multi-environment trial data. Crop Sci. 41: 656-663.

[17] Yan, W. 2002. Singular-value portioning in biplot analysis of multi-environment trial data. Agron. J. 94: 990-996.

[18] Fortin, M. C. and Pierce, F. J. (1990). Developmental and growth effects of crop residues on corn. Agronomy Journal, 82: 710-715.

[19] Andrew Abiodun Efisue, Cynthia Chimezie Dike. Screening Rice (Oryza sativa. L.) for Salinity Tolerance for Yield and Yield Components in Saline Stressed Environment. American Journal of Agriculture and Forestry. Vol. 8, No. 1, 2020, pp. 15-21. doi: 10.11648/j.ajaf.20200801.13.

[20] Andrew Abiodun Efisue, Ella Elizabeth Igoma. Screening Oryza Sativa L. for Salinity Tolerance During Vegetative Stage for the Coastal Region of Niger-Delta Nigeria. Journal of Plant Sciences. Vol. 7, No. 1, 2019, pp. 21-26. doi: 10.11648/j.jps.20190701.14.

[21] Fageria N. K. and Santos A. B. (2014). Requirement of Micronutrients by Lowland Rice. Soil Science and Plant Analysis, 45: 844-863.

[22] Yu-Ping Yan, Jun-Yu He, Cheng Zhu, Chang Cheng, Xue-Bo Pan and Zhong-Yang Sun (2006). Accumulation of copper in brown rice and effect of copper on rice growth and grain yield in different rice cultivars. Chemosphere 65 (10): 1690-1696. DOI: 10.1016/j.chemosphere.2006.05.022.

[23] Jiakuan $\mathrm{Xu}$, Lianxin Yang, Ziqiang Wang, Guichun Dong, Jianye Huang and Yulong Wang (2006). Toxicity of copper on rice growth and accumulation of copper in rice grain in copper contaminated soil. Chemosphere 62 (4): 602-7, DOI: 10.1016/j.chemosphere.2005.05.050.

[24] Efisue, A. A., Umunna, B. C. and Joseph, A. O., 2014. Effect of yield and yield components on yield potential of some lowland rice (Oryza satia. L.) in coastal region of southern Nigeria. Journal of Plant Breeding and Crop Science, 6 (9), pp. 119-127.

[25] Exonam Amegan, Andrew Efisue, Malachy Akoroda, Afeez Shittu, Fiot Tonegnikes. Genetic Diversity of Korean Rice (Oryza Sativa L.) Germplasm for Yield and Yield Related Traits for Adoption in Rice Farming System in Nigeria. International Journal of Genetics and Genomics. Vol. 8, No. 1, 2020, pp. 19-28. doi: 10.11648/j.ijgg.20200801.13.

[26] Immanuel, S. C., Pothiraj, N., Thiyagarajan, K., Bharathi, M. and Rabindran, R. (2011). Genetic parameters of variability, correlation and pathcoefficient studies for grain yield and other yield Attributes among rice blast disease resistant genotypes of rice (Oryza sativa L.). African Journal of Biotechnology, 10 (17): 3322-3334.

[27] Yan, W., Hunt, L. A. Sheng, Q. and Szlavnics, Z. (2000). Cultivar evaluation and mega-environment investigation based on the GGE biplot. Crop Science, 40: 597-605. 